\title{
In Silico Structural Analysis of The Cell Division Protein, FtsZ: Screening Natural Products for Inhibitors
}

\section{Mohammed Zaghlool Al-Khayyat ${ }^{1}$, Ammar Ghanem Al- Dabbagh $^{2}$, Yousra Abdul-Razaq Al-refaie ${ }^{1}$}

${ }^{1}$ Biology Department, College of Education for Pure Sciences, University of Mosul. ${ }^{2}$ Biology Department, College of Science, University of Mosul.

Received

14/02/2018
Accepted

11/04/2018

\section{الخلاصة}

البروتين FtsZ هو مناظر للتوبيلين إذ يثكل حلقة Z لجذب البروتينات الاخرى في عملية الانقسام الخلوي من خلال فعالية GTPase الخاصة به. تم الحصول على تسلسل الاحماض الامينية للبروتين من قاعدة البيانات Uniport واستخدم التسلسل في تحديد التركيب الاولي والثانوي من خلال برامجيات المعلوماتية الحيوية في الثبكة العنكبوتية. بني التركيب الثالثي للبروتين باستخدام طريقة النمذجة المتتاظرة بواسطة برنامجي SWISS-MODEL و PHYRE2 والتي اثتتت البرامجيات الخاصة بتقييم نوعية البروتين ان النموذج المبني من قبل SWISS-MODEL اكثر دقة من الاخر

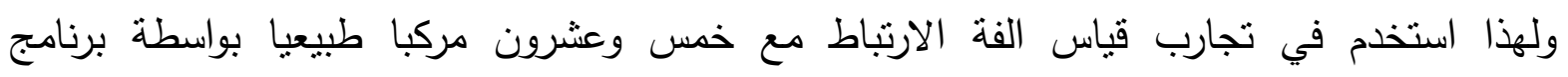

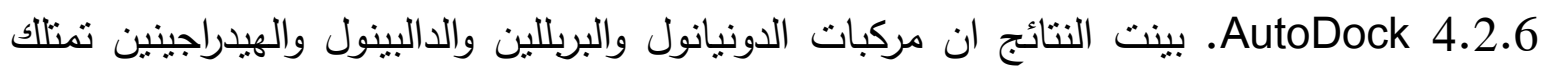
الفة ارتباط اكبر من البيربين والسانكيورانين. تم تصميم نظائر تركيبية للدونيانول باستخدام برنامج

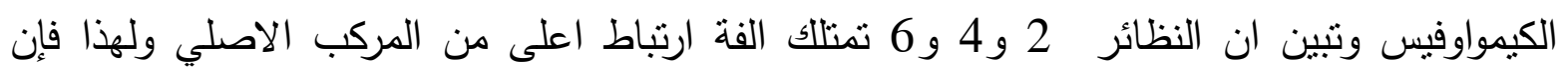
المركبات الطبيعية ونظائرها المستخدمة في هذه الدراسة ممكن ان تستغل كمثبطات محتملة لبروتينات الانقسام الخلوي كهدف جديد في تصميم المضادات الحيوية.

الكلمات المفتاحية: اوتودوك4.2.6 ، الدونيانول، النمذجة المتناظرة، المعلوماتية الحيوية.

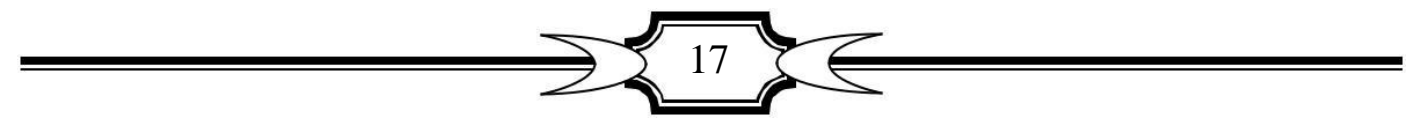




\begin{abstract}
FtsZ is a tubulin homolog in bacteria. It forms a Z-ring to recruit other proteins in the process of cell division through its GTPase activity. Amino acid sequence of FtsZ was obtained from uniprot database and used for the determination of primary and secondary structures by several online tools. Homology modeling was carried out by SWISS-MODEL and PHYRE2. The models were evaluated and quality assessment indicated that the model produced by SWISS-MODEL had better quality than PHYRE2. Therefore, SWISS-MODEL was used in docking twenty five natural products by AutoDock 4.2.6. Dunnianol, pebrellin, dalbinol and hederagenin had docking energy higher than the previously used berberine and sanguinarine. Analogs of Dunnianol were sketched by ChemBioOffice Ultra 11.0 and docked. The analogs 2,4 and 7 had higher docking energy than the original compound. These natural products and the analogs obtained in this study could serve as possible inhibitors of this cell division protein, a new target in the development of new antimicrobials.
\end{abstract}

Keywords: AutoDock 4.2.6, Dunnianol, Homology modeling, Bioinformatics.

\title{
Introduction
}

FtsZ is a tubulin-homolog protein which appears at the septum region during bacterial cytokinesis. FtsZ polymerizes in a GTP-dependent manner and forms a dynamic $\mathrm{Z}$ ring during cell division and acts in recruiting other division proteins [1-3].

FtsZ of Thermotoga maritima appears to contain four main domains. These domains are $\mathrm{N}$-terminal segment, a conserved core region in which the tubulin signature motif is located, a variable spacer and a $\mathrm{C}$-terminal peptide. The core region has two folded $\mathrm{N}$-terminal and $\mathrm{C}$-terminal segments. The $\mathrm{C}$ terminal segment binds the top of the adjacent monomer while the $\mathrm{N}$-terminal segment, which harbors the GTP binding site, binds the bottom of the adjacent monomer in the protofilament [4-6].

The dynamic FtsZ filaments bend and depolymerize on GTP hydrolysis and associate laterally to form polymers of double filaments and bundles. The Z-ring structure has been shown as a bundle of short FtsZ filaments, circling the plasma membrane from inside of the cell. The constriction of the Z-ring during cell division is mediated by the polymerization/ depolymerization cycles of FtsZ filaments [7-9].

To develop novel antimicrobials, researchers concentrated on the cavities available for ligand binding in a FtsZ monomer such as the nucleotide binding sites and the long cleft between GTP binding and C-terminal domains

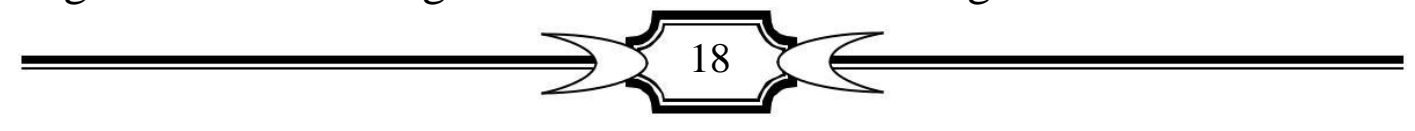


e.g. the difluoro-benzamide derivative PC190723 effectively inhibited bacterial cell division, being capable of protecting mice from Staphylococcus aureus infections [10-11].

The increase of size in sequences available in the data bases caused an increase in the prediction methods based on known structures of similar size[12,13]. Protein modeling can be used in design of drugs and studying protein functions and interactions [14]. Homology modeling relies on the fact that the 3D structure of proteins from the same family is more conserved than their amino acid sequences [15]. A sequence identity above $40 \%$ can generate a reliable model [16]. However, the side-chains may be less accurate geometrically [17]. In addition, most programs used in homology modeling cannot produce models when the sequence is more than 400 amino acids in length.

The aim of this study is to analyze the primary and secondary characteristics of this cell division protein and to predict a complete 3D structure of FtzZ protein of Enterococcus faecalis strain ATCC 700802 sequenced by Pucci and co-workers [18]. This 3D model is used in docking studies to find anti-FtsZ agents useful in development of new antimicrobials.

\section{Materials and methods}

1. Sequence retrieval, primary and secondary structure determination

Amino acid sequence of FtsZ was obtained from uniprot database available at http://www.uniprot.org/. FtsZ accession number: O08439. The molecular weight, amino acid composition, theoretical isoelectric point (pI), extinction coefficient [19], instability index [20], aliphatic index [21], and grand average of hydropathcity [22] were computed using the ProtParam tool of Expasy server (http://web.expasy.org/protparam/) [23]. Secondary structure was predicted by SSpro8 of SCRATCH (24), at http://scratch.proteomics.ics.uci.

edu/. The output of the program is according to Kabsch and Sander [25], hence H: alpha-helix, G: 3-10-helix, E: extended strand, T: turn, S: bend and C: the rest. Intrinsic disordered regions were detected by The IntFOLD server [26].

\section{Homology modeling of the 3D structure}

The protein tertiary structure was built by SWISS-MODEL [27] using (http://swissmodel.expasy.org/). After searching the SWISS-MODEL library, a template from $2.5 \mathrm{~A}^{\circ} \mathrm{X}$-ray structure of Bacillus subtilis cell division protein, FtsZ (PDB ID: 2VAM, chain B) was selected to generate the model. Alignment was constructed by Deep view/ Swiss-Pdb viewer [28] and edited by the alignment sequence editor [29], BioEdit 7.2.5. Another online automated server was used to generate a complete $3 \mathrm{D}$ model; the protein homology/analogy recognition engine [30], PHYRE2, can be accessed at 
(http://www.sbg.bio.ic.ac.uk/phyre2/html /page.cgi?id=index). The structures were visualized by Python molecular viewer [31].

\section{Evaluation of the 3D structures}

The models were evaluated by several validation tools to assess their quality. ERRAT[32] is a verification algorithm for evaluating model building and refinement (http://services.mbi.ucla.edu/ERRAT/).SWISS-MODEL workspace server [27] (http://swiss model.Expasy.org/workspace/) contains: (a) ANOLEA [33] which depends on a statistically derived knowledge-based mean force potential (b) Qualitative Model Energy Analysis tool [34], QMEAN6, estimates the global and local quality of the models (c) PROCHECK [35] for analysis of residues' geometry. The best model was submitted into the protein model database [36] (PMDB) available at: http://bioinformatics. cineca.it/PMDB.

\section{Molecular Docking}

The compounds used in screening for FtsZ inhibition were obtained from ZINC database [37] (http://zinc.docking.org/). Their .sdf format was converted to .pdb format using Open Babel software [38]. According to the method of Ashokan [39] and Modi et al. [40], substituted analogs were sketched by ChemBioDraw tool of ChemBioOffice Ultra 11.0. Package [41]. Prior to docking, the ligands were energy minimized by ChemBio3D tool of the same package to a minimum RMS gradient of 0.100 . Molecular properties were predicted by ChemAxon at: www.chemicalize.org.The Docking software, AutoDock 4.2.6 was used to dock ligands [42] by a Grid of $60 \times 60 \times 60$ as number of points in $\mathrm{x}, \mathrm{y}$, and $\mathrm{z}$ dimensions respectively, spacing: $0.375 \mathrm{~A}^{\circ}$, and a Grid box center of $29.011,-9.027$ and -2.488 for $\mathrm{x}, \mathrm{y}$ and $\mathrm{z}$ respectively.

\section{Results and discussion}

The physiochemical properties of FtsZ were computed using ProtParam tool. FtsZ contains 410 amino acids with a molecular weight of 44.475 Kilo Dalton. Total number of negatively charged residues (Asp + Glu) was 63 and total number of positively charged residues (Arg + Lys) was 43. Its theoretical pI was 4.77 , hence; this protein is acidic because the value is less than 7 . The extinction coefficient indicates how much light a protein could absorb at that wavelength [11]. The extinction coefficient of FtsZ at $280 \mathrm{~nm}$ is $8480 \mathrm{M}^{-1} \mathrm{~cm}^{-1}$. The instability index provides an estimate of the stability of the protein in a test tube. The instability index was 32.79 indicating a stable protein. The aliphatic index of FtsZ was 85.85 and the grand average of hydropathcity was -0.354 .

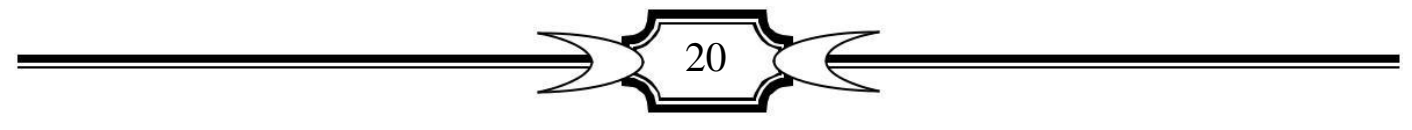


FtsZ of E. faecalis appears to have following topology: $\beta 1$ $\left(\mathrm{Val}^{14} \rightarrow \mathrm{Gly}^{21}\right), \alpha 1\left(\mathrm{Gly}^{22} \rightarrow \mathrm{Glu}^{34}\right), \beta 2\left(\mathrm{Glu}^{40} \rightarrow \mathrm{Asn}^{45}\right), \alpha 2\left(\mathrm{Val}^{48} \rightarrow \mathrm{Lys}^{52}\right), \beta 3$ $\left(\mathrm{Thr}^{58} \rightarrow \mathrm{Leu}^{62}\right), \alpha 3\left(\mathrm{Pro}^{64} \rightarrow \mathrm{Thr}^{67}\right), \alpha 4\left(\mathrm{Pro}^{76} \rightarrow \mathrm{Glu}^{84}\right), \alpha 5\left(\mathrm{Gln}^{88} \rightarrow \mathrm{Ser}^{93}\right), \beta 4$ $\left(\right.$ Asp $^{98} \rightarrow$ Ala $\left.^{104}\right), \quad \alpha 6 \quad\left(\operatorname{Thr}^{110} \rightarrow\right.$ Leu $\left.^{125}\right), \quad \beta 5 \quad\left(\operatorname{Leu}^{128} \rightarrow \operatorname{Arg}^{135}\right), \quad \alpha 7$ $\left(\mathrm{Pro}^{142} \rightarrow \mathrm{Asn}^{158}\right), \quad \beta 6 \quad\left(\mathrm{Asp}^{160} \rightarrow \mathrm{Asn}^{167}\right), \quad \alpha 8 \quad\left(\mathrm{Asn}^{168} \rightarrow \mathrm{Val}^{173}\right), \quad \alpha 9$ $\left(\mathrm{Met}^{180} \rightarrow \mathrm{Thr}^{203}\right), \quad \alpha 10 \quad\left(\mathrm{Phe}^{212} \rightarrow \mathrm{Phe}^{219}\right), \quad \beta 7 \quad\left(\mathrm{Gly}^{223} \rightarrow \mathrm{Ala}^{232}\right), \quad \alpha 11$ $\left(\mathrm{Arg}^{237} \rightarrow \mathrm{Ser}^{247}\right), \quad \beta 8 \quad\left(\mathrm{Glu}^{259} \rightarrow \mathrm{Gly}^{267}\right), \quad \alpha 12 \quad\left(\mathrm{Leu}^{273} \rightarrow \mathrm{Ala}^{286}\right), \quad \beta 9$ $\left(\mathrm{Asn}^{292} \rightarrow \mathrm{Asn}^{300}\right), \beta 10\left(\mathrm{ILe}^{307} \rightarrow \mathrm{Thr}^{314}\right)$ and $\alpha 13\left(\mathrm{Arg}^{330} \rightarrow \mathrm{Ala}^{332}\right)$.

SSpro8 provides a more detailed description of the secondary structure of FtsZ, where $32.9 \%$ of the residues lie in $\alpha$-helices, $17.3 \%$ of them lie in $\beta$ strands, $9.7 \%$ in $\beta$-turns, $4.1 \%$ in bends, $1.5 \%$ in $3-10$ helices, $0.7 \%$ in bridges and the rest (33.8\%) as random coils (Fig.1).

Fig. 2a, shows that last segment of the molecule starting from Lys ${ }^{323}$ is in the form of unstructured intrinsic region as predicted by IntFold server. These structurally instable disordered regions are not easily characterized in $\mathrm{X}$-ray experimental approaches. Intrinsically disordered proteins forms folded structures on binding their targets. Coupled folding and binding appear to play a critical role in the signaling activity of Rho family GTPases. These proteins play a role in signaling pathways that are essential for gene expression, the formation of the cytoskeleton and the cell cycle. These regions differ in amino acid composition from typical proteins since they are highly flexible and are characterized by amino acid compositional bias [43,44].

Four clefts and cavities were identified by Deep view/ Swiss-Pdb viewer (Fig. 2b); the largest one of an area $1718 \mathrm{~A}^{\circ 2}$ and a volume of $2244 \mathrm{~A}^{\circ 3}$. The second is of an area $656 \mathrm{~A}^{\circ 2}$ and a volume of $517 \mathrm{~A}^{\circ 3}$. The third one is of an area $394 \mathrm{~A}^{\circ 2}$ and a volume of $292 \mathrm{~A}^{\circ 3}$. The smallest one is of an area $393 \mathrm{~A}^{\circ 2}$ and a volume of $254 \mathrm{~A}^{\circ 3}$. 


\begin{abstract}
a- Amino Acid sequence
ME FS LDNNINNGAVIKVIGVGGGGGNAVNRMI EENVKGVEFITANTDVQALKH SKAE TVIQLGPKYTRGL GAGSQPEVGQKAAEE SEQVI SE SLQGADMI FI TAGM GGGTGTGAAPVVAKIAKELGALTVGVVTRPFS FEGPKRGRFAAEGIALLKENV DT LLIISNNRLLEVVDKKT PMLEAFREADNVLRQGVQGI SDL ITAPGYVNLDF ADVKTVMENQGTALMGI GVASGEERVIEATKKAI SSP LLETS IDGAEQVLLNI TGGLDMT LFEAQDA SDIVTNAA SGDVN I I LGT SINED LGDEI RVTVIATGIDE

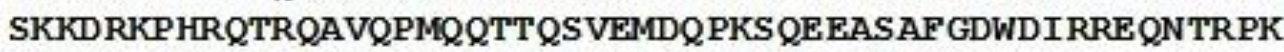
VDES SLEQVDKKEFDTFHREEPNHNDDELSTP PF FRRKR
\end{abstract}

\title{
b-Predicted Secondary Structure (8 Class)
}

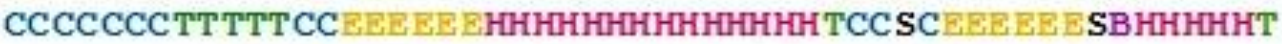 CCCS EEE ECCHННН TTBCC TTCHННННННННН THНННННННT TCS EE EEEETT

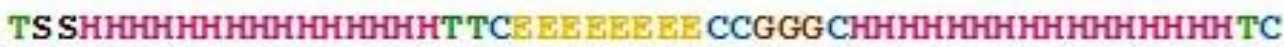

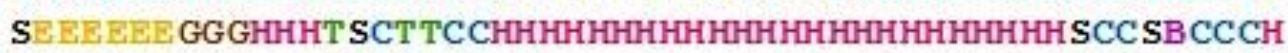 ННННННН TTCEЕ EE EEE EE ECS TTHНHННННННН TCT TCSSCCT TCS EE EE EE ВE CT TCCHННННННННННННS CT TCE EE EEEEE CTTCS SCE EE EEEEE CCCC

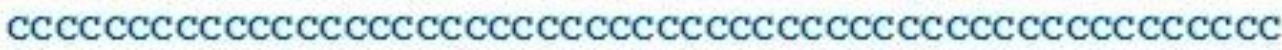

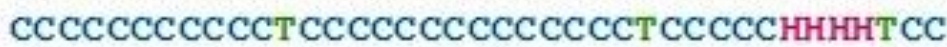

Fig. 1(a) Amino acid sequence of FtsZ, letters represents amino acids according to standard IUB/IUPAC amino acid codes. (b) The SSpro8 prediction of the secondary structure components classified according to Kabsch and Sander [25]: H: alpha-helix, G: 3-10-helix, E: extended strand, T: $\beta$-turn, $\mathrm{S}$ : bend, B: bridges and $\mathrm{C}$ : the rest.

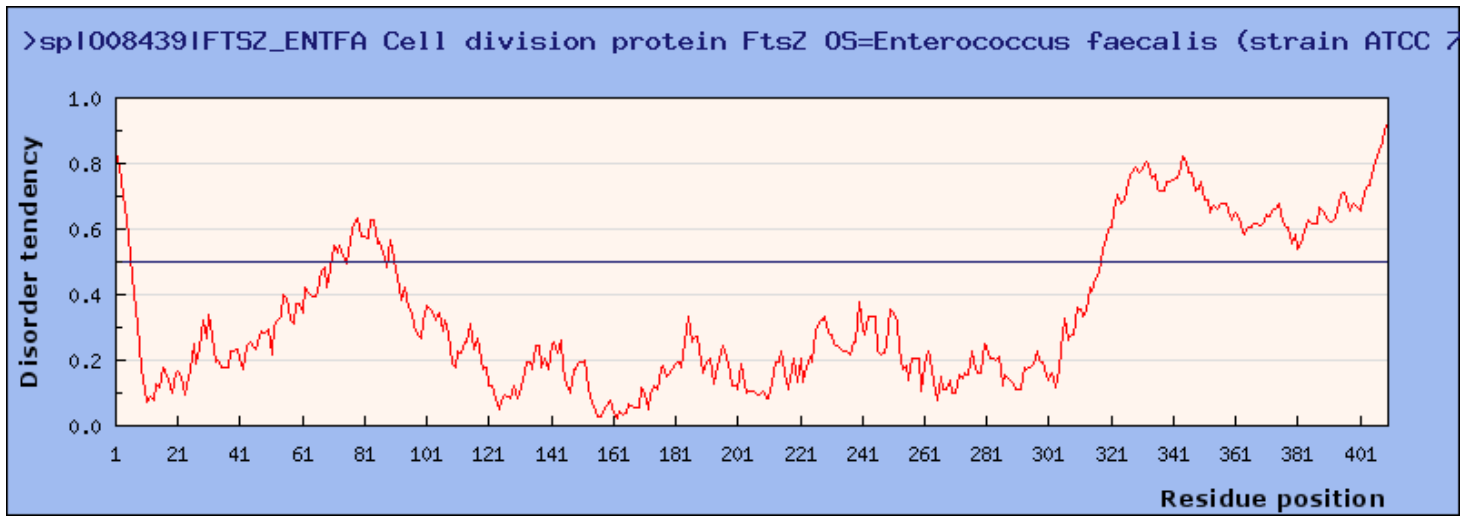

(a)

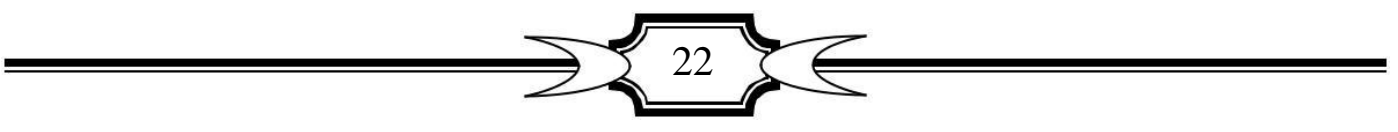




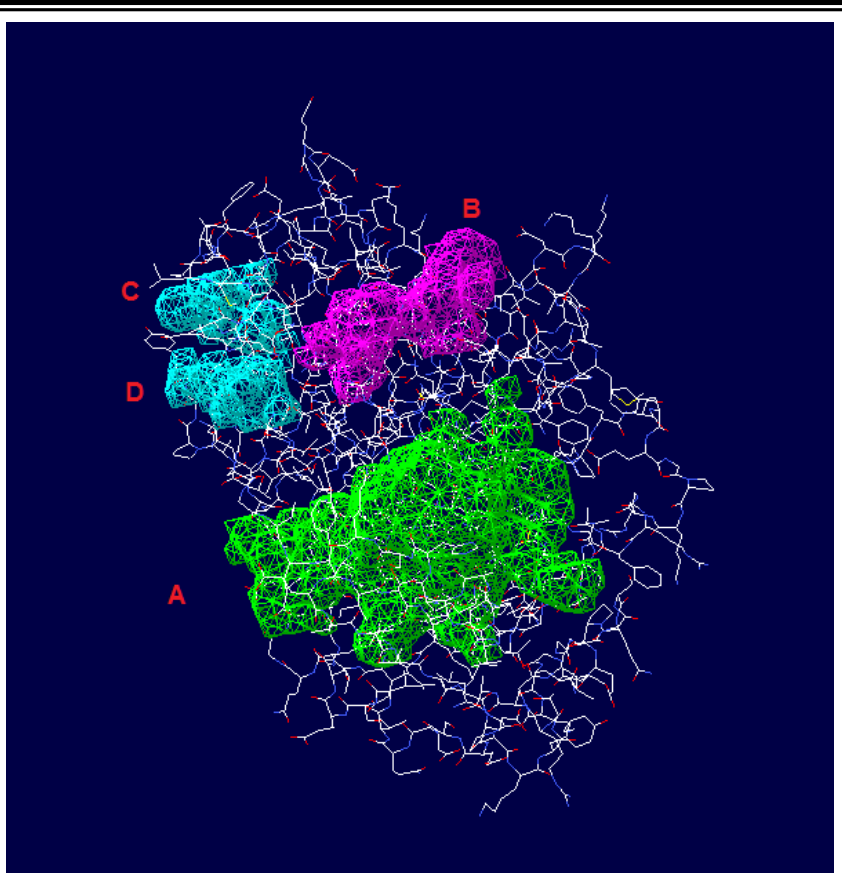

(b)

Fig. 2(a) Intrinsic disorder region prediction by IntDOLD server. (b) Clefts and cavities of FtsZ molecule (A-D in the order of sizes; 2244, 517, 292 and $393 \mathrm{~A}^{\circ 3}$ respectively), identified by Deep view/Swiss Pdb viewer. 


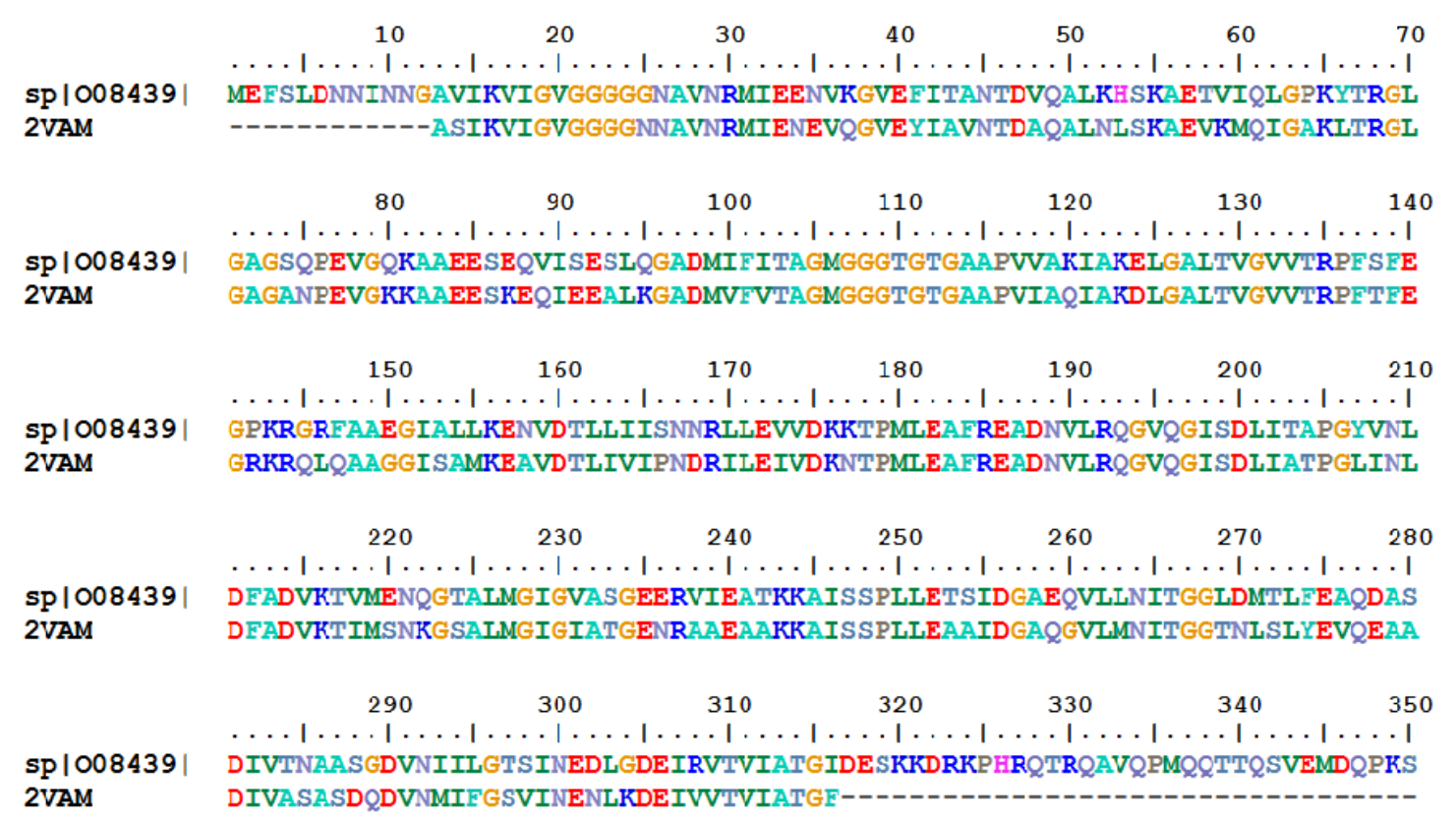

Fig. (3) Alignment of FtsZ sequence which belongs to E. faecalis, sp|O08439| with the template of Bacillus subtilis, PDB ID: 2VAM to show similarity between the two sequences as initial step in homology modeling. Viewed by BioEdit 7.2.5.

Using SWISS-MODEL, a template from Bacillus subtilis cell division protein was selected to generate a model extending from $\mathrm{Ala}^{13}$ to $\mathrm{ILe}^{316}$ amino acid residues. Fig. 3 shows the alignment of this template with the target sequence and Fig. 4(a), shows the predicted model of this sequence.

PHYRE2 uses a library of known protein structures taken from Structural Classification of Proteins (SCOP) database [45]. Although the PHYRE2 system uses a powerful loop modeling techniques to model insertions and repair deletions in the alignment but it fails when such deletion is more than 15 residues in length [30]. A 3D model was also generated by PHYRE2 (Fig. 4b) using $2.7 \mathrm{~A}^{\circ} \mathrm{X}$-ray structure of Methanocladococcus jannaschii, FtsZ dimer (PDB code: c1w59, chain B) as a template, since no experimental X-ray crystallographic structure is available for E. faecalis. Only $329(80 \%)$ of the residues were built by this template and 19 other templates of cell division proteins including FtsZ and a phylogenetically related tubulin-like plasmid partition proteins were used to build a full length model. Their PDB codes are c2vawA, c1w5fA, c2r6r1, c1 ofuB, c2vxyA, c4dxdA, c2rhoB, c4ebeA, c2q1yB, c4b45A, c4b46A, c4ei8A, c3v3tA, c3zidB, c3rb8A, c3m8kA, d2vapa1, d1ofua1 and d1rq2a1. These templates are available in Protein Data Bank at https://www.rcsb.org/ 
Validation tools use statistical potentials via $\mathrm{C}_{\alpha} / \mathrm{C}_{\beta}$ atoms and all atoms potentials or by estimating solvent accessibility, atomic distances and torsion angles [46]. Other methods are used to assess the model by measuring its geometrical features and comparing them with those in the experimentally determined high resolution structures of similar size [35].

QMEAN6 is an abbreviation of Qualitative Model Energy Analysis and represents a composite of six linear descriptors. These are; two $C_{\beta}$ atom and all atom potentials, torsion angle potentials, solvation potentials are calculated. Also, the agreement between the calculated and the predicted secondary structure and solvent accessibility are included. The raw scores range between 0-1 in good reliable models [34]. SWISS-MODEL had higher QMEAN6 score (0.69) than PHYRE2 model (0.64).

ERRAT is a method for detecting incorrect regions of protein structures based on the principle that errors lead to random distributions of atoms. ERRAT is a program for evaluating the correctness of structures and the program was effective in identifying erroneous regions of model structures, and is useful during the process of building and refining i.e. correcting crystal structures, hence the name, ERRAT. The ERRAT program classifies atoms into three types $(\mathrm{C}, \mathrm{N}$, and $\mathrm{O})$ and checks whether the distribution of nonbonded interactions $(\mathrm{CC}, \mathrm{CN}, \mathrm{CO}, \mathrm{NN}, \mathrm{NO}$ and $\mathrm{OO}$ ) between atoms in a structure coincides with the normal distribution of a database represents known high resolution structures [32]. Fig. 5 shows that SWISS-MODEL having better quality $(91.04 \%)$ than the PHYRE2 model which contains many erroneous regions and displays a low model quality of $71.39 \%$. The non-local energy profile of both models as predicted by ANOLEA is shown in Fig. 6 .

Ramachandran plot values of SWISS-MODEL in PROCHECK were $96.3 \%, 3.3 \%, 0.0 \%$ and $0.4 \%$ for the residues in the most favored regions, the residues in the additionally allowed regions, the residues in generously allowed regions and the residues in disallowed regions respectively, whereas for PHYRE2 model the residues in the same regions had $88.1 \%, 8.5 \%, 2.3 \%$ and $1.1 \%$ respectively. Tables 1 and 2 show a comparison between the stereochemical parameters of the PHYRE2 model and the Model produced by SWISS-MODEL in respect to the main and side chain parameters respectively. Ramachandran plots of PHYRE2 model and the SWISS-MODEL are shown in Fig. 7.

In a polypeptide the bonds of the main chain $\mathrm{N}-\mathrm{C} \alpha$ and $\mathrm{C} \alpha-\mathrm{C}$ relatively rotates and the rotations are represented by two torsion angles phi and psi, respectively. Ramachandran used this plot to view these phi and psi torsion angles. The red regions correspond to conformations where there are no steric clashes, i.e. these are the allowed regions for the $\alpha$-helices and $\beta$-sheets. The 
yellow areas show the allowed regions if the atoms come a little closer together. Disallowed regions generally involve steric hindrance between the side chain C- $\beta$ methylene group and main chain atoms. According to Ramachandran plot of more than 118 structures, a good quality model is that having more than $90 \%$ of its residues in the most favored region [35].

Results indicate that the Model produced by SWISS-MODEL is superior to that of PHYRE2. The model constructed by SWISS-MODEL was submitted successfully into the protein model database (PMDB) and had an ID: PM0079979.

Demchuk et al. [47] performed a study on homology modeling of FtsZ based on a template of Mycobacterium tuberculosis present in protein data bank. Five models of FtsZ belonged to Escherichia coli were generated by ITASSER online server and were evaluated by MolProbity tool, DFIRE and QMEAN6. The percentages of the residues in the most favored region ranged between $89.50 \%-92.65 \%$. The percentages of residues in the outliers ranged from $1.84 \%$ to $3.94 \%$. QMEAN6 scores were $0.59-0.63$.

Table 1a-Summary of the main-chain parameters of SWISS-MODEL in Ramachandran plot

\begin{tabular}{|l|c|c|c|c|c|c|}
\hline Stereochemical quality & $\begin{array}{c}\text { No. of } \\
\text { data } \\
\text { points }\end{array}$ & $\begin{array}{c}\text { Parameter } \\
\text { value }\end{array}$ & $\begin{array}{c}\text { Typical } \\
\text { value }\end{array}$ & $\begin{array}{c}\text { Value } \\
\text { band } \\
\text { width }\end{array}$ & $\begin{array}{c}\text { No. of band } \\
\text { widths from } \\
\text { mean }\end{array}$ & Interpretation $^{2}$ \\
\hline \% residues in A, B, L & 245 & 96.3 & 76.6 & 0.0 & 2.0 & BETTER \\
\hline Omega angle SD & 286 & 4.2 & 6.0 & 3.0 & -0.6 & Inside \\
\hline $\begin{array}{l}\text { Bad contact/100 } \\
\text { residues }\end{array}$ & 5 & 1.7 & 10.5 & -0.9 & -0.9 & Inside \\
\hline Zeta angle SD & 255 & 1.4 & 3.1 & 1.6 & -1.1 & BETTER \\
\hline H-bond energy SD & 191 & 0.7 & 0.9 & 0.2 & -1.0 & Inside \\
\hline Overall G-factor & 287 & 0.1 & -0.6 & 0.3 & 0.3 & BETTER \\
\hline
\end{tabular}

${ }^{1} \mathrm{SD}$ denotes the standard deviation of the score observed, ${ }^{2}$ the accuracy of a structure (interpretation) is depicted in the order of Better > Inside > Worse for each parameter.

Table 1b-Summary of the main-chain parameters of PHYRE2 in Ramachandran plot

\begin{tabular}{|l|c|c|c|c|c|c|}
\hline Stereochemical quality & $\begin{array}{l}\text { No. of } \\
\text { data } \\
\text { points }\end{array}$ & $\begin{array}{c}\text { Parameter } \\
\text { value }\end{array}$ & $\begin{array}{c}\text { Typical } \\
\text { value }\end{array}$ & $\begin{array}{c}\text { Value } \\
\text { band } \\
\text { width }\end{array}$ & $\begin{array}{c}\text { No. of band } \\
\text { widths from } \\
\text { mean }\end{array}$ & Interpretation $^{2}$ \\
\hline \% residues in A, B, L & 353 & 88.1 & 76.6 & 10.0 & 1.2 & BETTER \\
\hline Omega angle SD & 407 & 4.4 & 6.0 & 3.0 & -0.5 & Inside \\
\hline $\begin{array}{l}\text { Bad contact/100 } \\
\text { residues }\end{array}$ & 8 & 2.0 & 10.5 & 10.0 & -0.9 & Inside \\
\hline Zeta angle SD & 370 & 1.4 & 3.1 & 1.6 & -1.1 & BETTER \\
\hline H-bond energy SD & 248 & 0.8 & 0.9 & 0.2 & -0.7 & Inside \\
\hline Overall G-factor & 410 & -0.1 & -0.6 & 0.3 & 1.7 & BETTER \\
\hline
\end{tabular}

${ }^{1} \mathrm{SD}$ denotes the standard deviation of the score observed, ${ }^{2}$ the accuracy of a structure (interpretation) is depicted in the order of Better > Inside > Worse for each parameter. 
Mohammed Z. Al-Khayyat, Ammar Gh. Al-Dabbagh \&Yousra A. Al-refaie

\begin{tabular}{|l|c|c|c|c|c|c|}
\hline \hline \multicolumn{6}{c|}{ Table 2a-Summary of the side-chain parameters of SWISS-MODEL in Ramachandran plot } \\
\hline Stereochemical quality & $\begin{array}{c}\text { No. of } \\
\text { data } \\
\text { points }\end{array}$ & $\begin{array}{c}\text { Parameter } \\
\text { value }\end{array}$ & $\begin{array}{c}\text { Typical } \\
\text { value }\end{array}$ & $\begin{array}{c}\text { Value } \\
\text { band } \\
\text { width }\end{array}$ & $\begin{array}{c}\text { No. of band } \\
\text { widths from } \\
\text { mean }\end{array}$ & Interpretation $^{2}$ \\
\hline Chi-1gauch minus SD $^{1}$ & 50 & 6.4 & 22.7 & 6.5 & -2.5 & BETTER \\
\hline Chi-1 trans SD & 78 & 9.7 & 22.7 & 5.3 & -2.5 & BETTER \\
\hline Chi-1 guache plus SD & 89 & 10.9 & 21.3 & 4.9 & -2.1 & BETTER \\
\hline Chi-1 pooled SD & 217 & 9.5 & 22.0 & 4.8 & -2.6 & BETTER \\
\hline Chi-2 trans SD & 79 & 9.0 & 23.1 & 5.0 & -2.8 & BETTER \\
\hline
\end{tabular}

${ }^{1} \mathrm{SD}$ denotes the standard deviation of the score observed, ${ }^{2}$ the accuracy of a structure (interpretation) is depicted in the order of Better > Inside > Worse for each parameter.

Table 2b-Summary of the side-chain parameters of PHYRE2 in Ramachandran plot

\begin{tabular}{|l|c|c|c|c|c|c|}
\hline Stereochemical quality & $\begin{array}{c}\text { No. of } \\
\text { data } \\
\text { points }\end{array}$ & $\begin{array}{c}\text { Parameter } \\
\text { value }\end{array}$ & $\begin{array}{c}\text { Typical } \\
\text { value }\end{array}$ & $\begin{array}{c}\text { Value } \\
\text { band } \\
\text { width }\end{array}$ & $\begin{array}{c}\text { No. of band } \\
\text { widths from } \\
\text { mean }\end{array}$ & Interpretation $^{2}$ \\
\hline Chi-1 gauche minus SD & 49 & 6.1 & 22.7 & 6.5 & -2.6 & BETTER \\
\hline Chi-1 trans SD & 104 & 9.0 & 22.7 & 5.3 & -2.6 & BETTER \\
\hline Chi-1 guache plus SD & 167 & 8.4 & 21.3 & 4.9 & -2.6 & BETTER \\
\hline Chi-1 pooled SD & 320 & 8.3 & 22.0 & 4.8 & -2.8 & BETTER \\
\hline Chi-2 trans SD & 101 & 10.1 & 23.1 & 5.0 & -2.6 & BETTER \\
\hline
\end{tabular}

${ }^{1} \mathrm{SD}$ denotes the standard deviation of the score observed, ${ }^{2}$ the accuracy of a structure (interpretation) is depicted in the order of Better > Inside > Worse for each parameter.

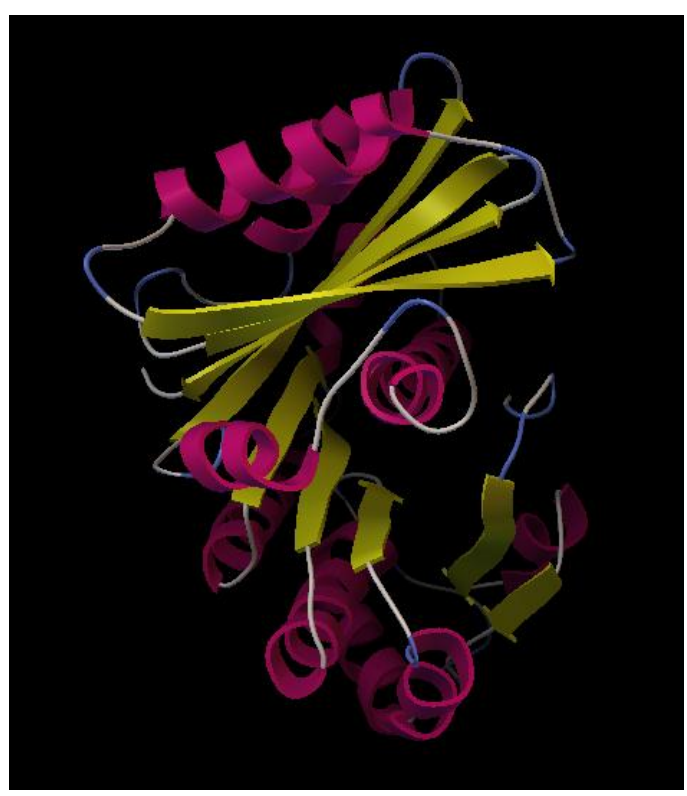

(a)

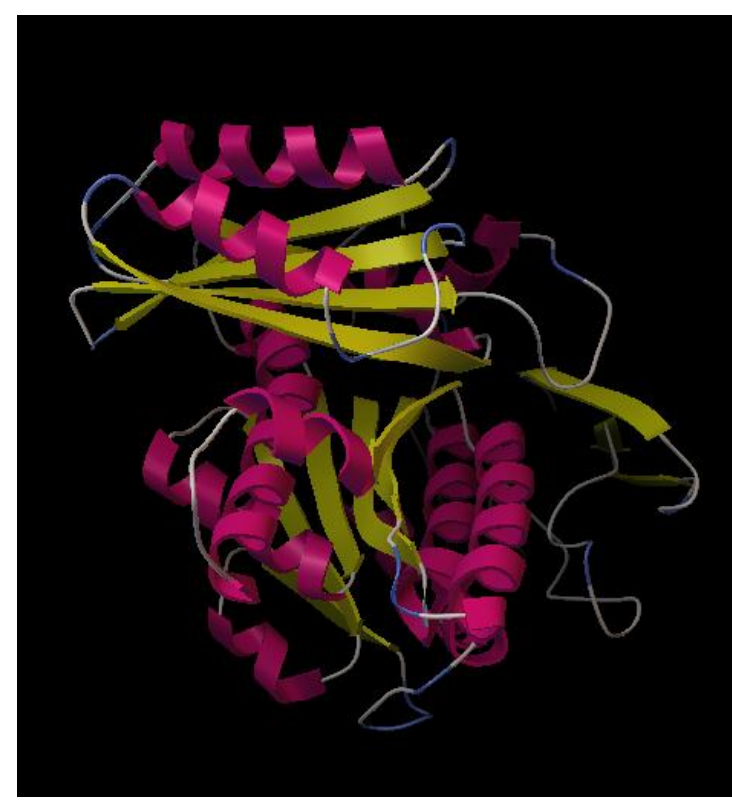

(b)

Fig. 4-Three dimensional structure of FtsZ built by (a) SWISS-MODEL (b) PHYRE2. $\beta$-stands appears yellow in color while $\alpha$-helices are pink, visualized by Python molecular viewer. 


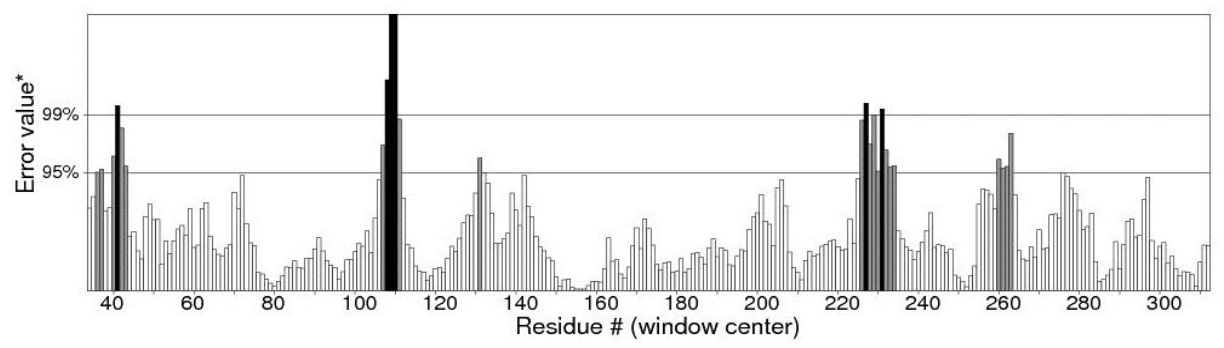

(a)

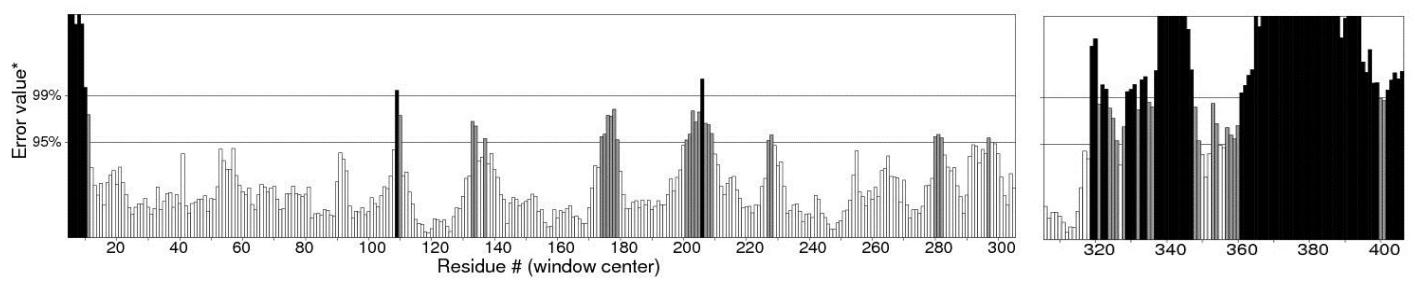

(b)

Fig. 5-ERRAT results of the FtsZ. Black bars represent misfolded regions. On the error axis two lines are drawn to indicate the confidences with which it is possible to reject regions that exceed that error value (a) SWISS-MODEL (b) PHYRE2. 


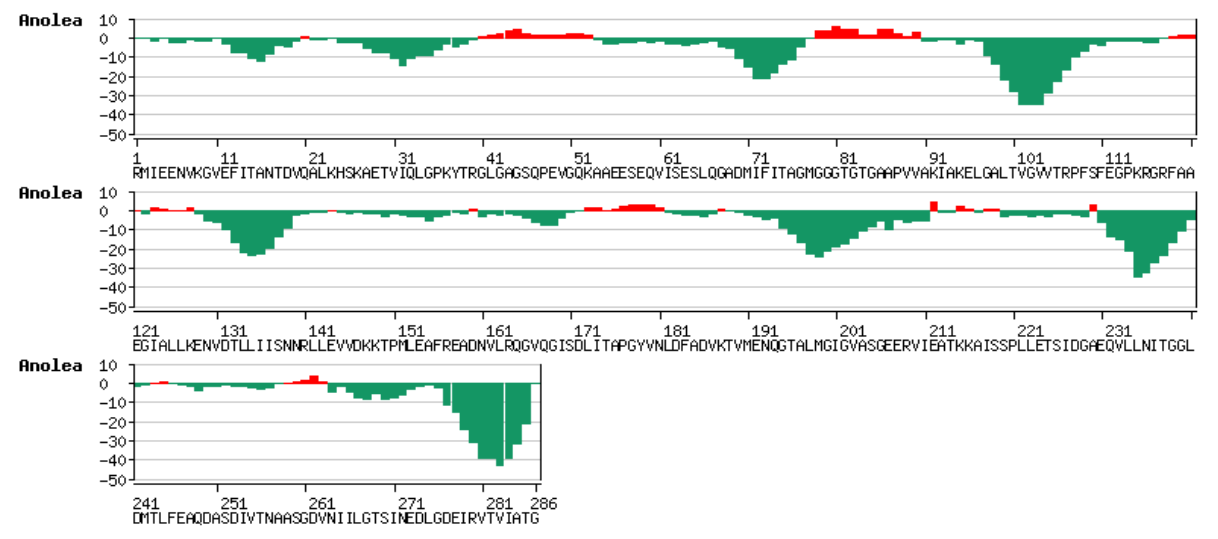

(a)

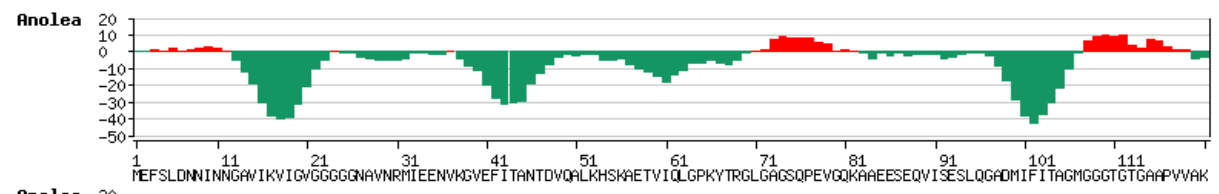

Anolea

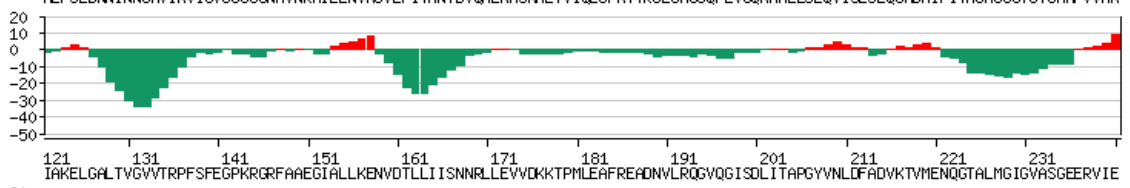

Anolea

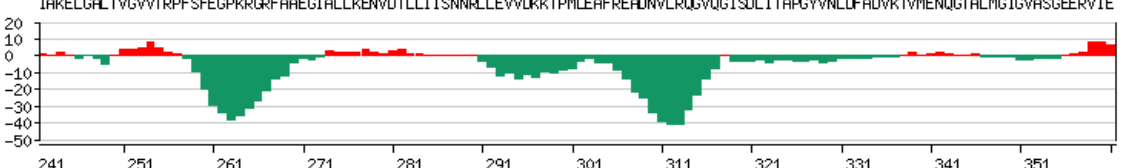

Anolea

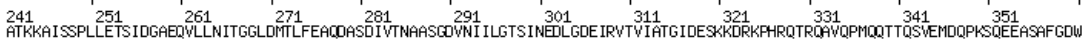

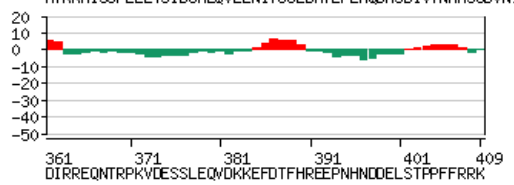

(b)

Fig. 6-ANOLEA plot of the non-local (overall) energy profile (a) SWISSMODEL (b) PHYRE2, high energy zones are red. 


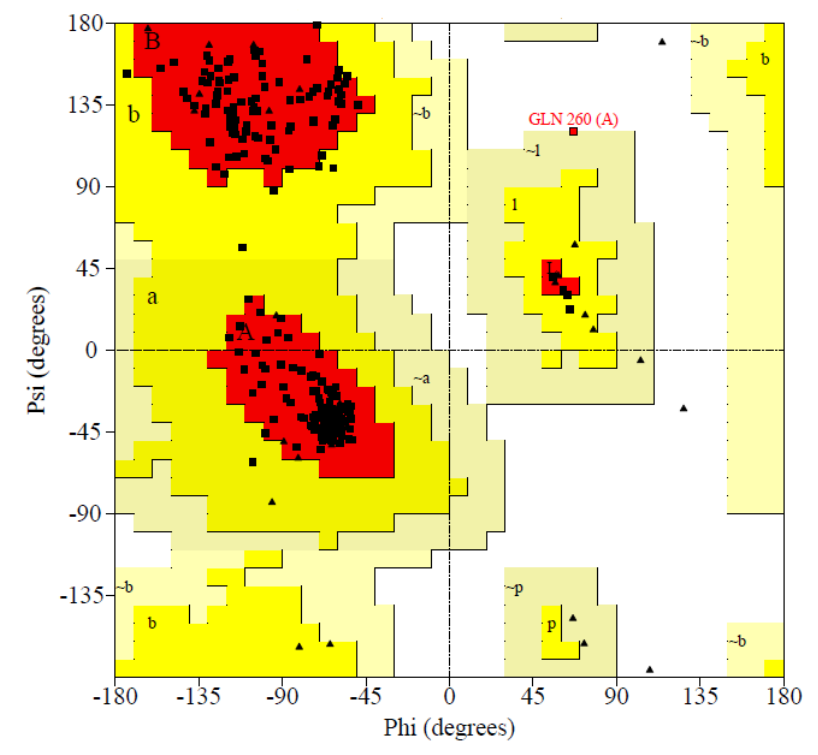

(a)

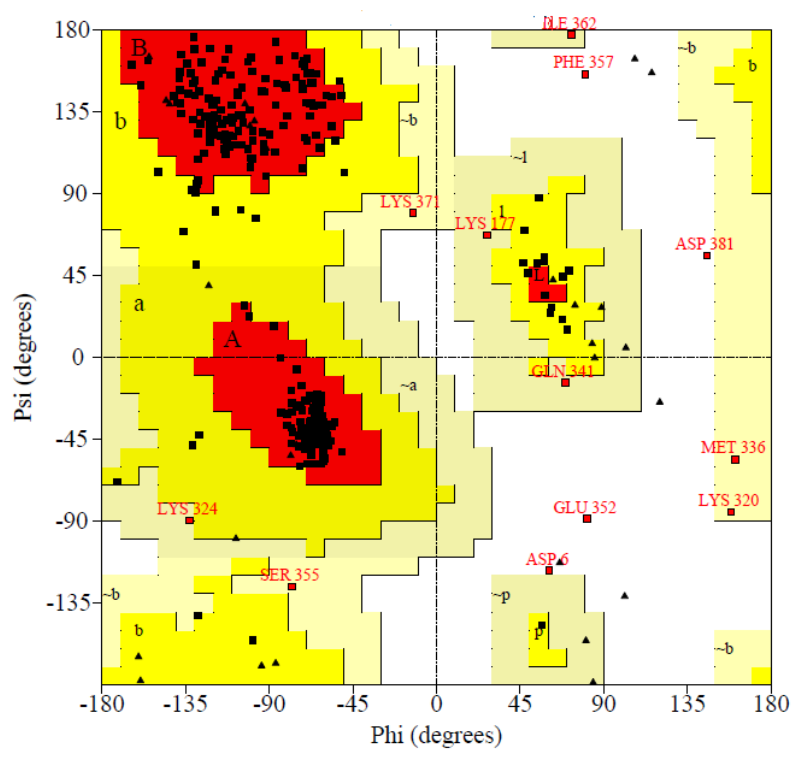

(b)

Fig. 7-Ramachandran plot of FtsZ by PROCHECK (a) SWISS-MODEL (b) PHYRE2. The most favored regions are marked as A, B, and L (red-colored areas). The additional allowed regions are marked as a, b, 1 , and $\mathrm{p}$ (yellowcolored areas). Residues in generously allowed regions as $\sim \mathrm{a}, \sim \mathrm{b}, \sim 1, \sim \mathrm{p}$ (lightbrown colored areas). All non-glycine and proline residues are shown as filled black squares, whereas glycines (non-end) are shown as filled black triangles. Disallowed amino acid residues are red-colored squares.

Twenty five compounds were screened by AutoDock 4.2.6. Table 3 shows the docking energy of the natural products of the highest scores. Berberine and Sanguinarine were used as positive controls since Kapoor and Panda [48] stated that Berberine, an alkaloid from Berberis aquifolium, possessed an anti-FtsZ activity. Sanguinarine [49] is a benzophenanthridine alkaloid extracted from the rhizomes of Sanguinaria Canadensis. Sanguinarine also inhibits bacterial division by interfering with FtsZ polymer assembly in $E$. coli [50].

Dunnianol (Fig. 8a) is a sesquilignan found in the stem bark of Illicium simonsii [51]. Dunnianol had the highest energy score among natural products screened. Seven analogs (Fig. 8, b-h) of this compound were sketched by 
ChemBioDraw Ultra. These analogs were also docked (Table 4, 5). Analog-2, Analog-4 and Analog-7 had highr docking score than the original compound.

Table 3-AutoDock results of the compounds against FtsZ

\begin{tabular}{|c|c|c|c|c|c|c|}
\hline Compound & ZINC ID & $\begin{array}{c}\text { Binding } \\
\text { energy } \\
(\mathrm{Kcal} / \mathrm{mol})\end{array}$ & $\begin{array}{c}\mathrm{K}_{\mathrm{i}}^{*} \\
(\mathrm{nM})\end{array}$ & $\begin{array}{c}\text { Intermolecular } \\
\text { energy } \\
(\mathrm{Kcal} / \mathrm{mol})\end{array}$ & $\begin{array}{c}\text { Internal } \\
\text { energy } \\
(\mathrm{Kcal} / \mathrm{mol})\end{array}$ & $\begin{array}{c}\text { Docking } \\
\text { energy** } \\
(\mathrm{Kcal} / \mathrm{mol})\end{array}$ \\
\hline Berberine & ZINC03779067 & -10.01 & 46.19 & -10.60 & -0.09 & -10.69 \\
\hline Sanguinarine & ZINC00000706 & -10.37 & 25.08 & -11.26 & 0.00 & -11.26 \\
\hline Dunnianol & ZINC15148440 & -10.88 & 10.64 & -14.16 & -1.50 & -15.66 \\
\hline Pebrellin & ZINC14437306 & -8.67 & 441.52 & -10.76 & -2.65 & -13.41 \\
\hline Dalbinol & ZINC13431280 & -10.20 & 33.49 & -11.99 & -1.09 & -13.08 \\
\hline Hederagenin & ZINC38605859 & -10.37 & 25.22 & -11.56 & -1.38 & -12.94 \\
\hline Hinokinin & ZINC01872258 & -8.85 & 324.14 & -10.05 & -0.63 & -10.68 \\
\hline Rotenone & ZINC03860715 & -9.11 & 211.8 & -10.00 & -0.66 & -10.66 \\
\hline
\end{tabular}

$* \mathrm{~K}_{\mathrm{i}}$ is the inhibition constant, **Docking energy is the sum of intermolecular and internal energies.

Table 4: Molecular descriptors of Dnnianol and its analogs

\begin{tabular}{|c|c|c|c|c|c|}
\hline Compound & IUPAC Name & $\begin{array}{l}\text { Mass } \\
(\mathrm{g} / \mathrm{mol})\end{array}$ & $\log \mathrm{P}^{*}$ & $\mathrm{RB}^{* *}$ & PSA $* * *$ \\
\hline Dunnianol & $\begin{array}{l}\text { (1R, 2S, 4S, 6S)-2,6-bis[(1R, 2S, 5S)-2-hydroxy-5- } \\
\text { propylcyclohexyl]-4-propylcyclohexan-1-ol }\end{array}$ & 422.6841 & 6.12 & 8 & 60.69 \\
\hline Analog-1 & $\begin{array}{l}\text { (1R, 2S, 4R, 6S)-2-[(1S, 2R, 5R)-2-hydroxy-5- } \\
\text { propylcyclohexyl]-6-[(1S, 2R, 5R)-2- } \\
\text { (hydroxymethyl)-5-propylcyclohexyl]-4- } \\
\text { propylcyclohexan-1-ol }\end{array}$ & 436.7107 & 6.36 & 9 & 60.69 \\
\hline Analog-2 & $\begin{array}{l}\text { (1S, 2S, 4R, 6S)-2-[(1S, 2S, 5S)-2-amino-5- } \\
\text { propylcyclohexyl]-6-[(1S, 2R, 5S)-2- } \\
\text { (hydroxymethyl)-5-propylcyclohexyl]-4- } \\
\text { propylcyclohexan-1-ol }\end{array}$ & 435.7259 & 6.25 & 9 & 66.48 \\
\hline Analog-3 & $\begin{array}{l}\text { (1S, 2S, 4R, 6S)-2-[(1S, 2S, 5S)-2-amino-5- } \\
\text { propylcyclohexyl]-6-[(1S, 2R, 5S)-2-methyl-5- } \\
\text { propylcyclohexyl]-4-propylcyclohexan-1-ol }\end{array}$ & 419.7265 & 7.61 & 8 & 46.25 \\
\hline Analog-4 & $\begin{array}{l}\text { (1S, 2S, 4S, 6S)-2-[(1R, 2S, 5S)-2-hydroxy-5- } \\
\text { propylcyclohexyl]-6-[(1R, 2S, 5S)-2-phosphoroso- } \\
\text { 5-propylcyclohexyl]-4-propylcyclohexan-1-ol }\end{array}$ & 452.6499 & 5.92 & 9 & 57.53 \\
\hline Analog-5 & $\begin{array}{l}(1 \mathrm{R}, 2 \mathrm{~S}, 4 \mathrm{R}, 6 \mathrm{~S})-2-[(1 \mathrm{R}, 2 \mathrm{~S}, 5 \mathrm{~S})-2 \text {-hydroxy-5- } \\
\text { propylcyclohexyl]-4-propyl-6-[(1R, 3S)-3- } \\
\text { propylcyclohexyl]cyclohexan-1-ol }\end{array}$ & 406.6847 & 7.43 & 8 & 40.46 \\
\hline Analog-6 & $\begin{array}{l}\text { (1R, 2S, 4R, 6S)-2-[(1R, 2S, 5S)-2-hydroxy-5- } \\
\text { propylcyclohexyl]-6-[(1R, 2R, 5S)-2- } \\
\text { (hydroxymethyl)-5-propylcyclohexyl]-4- } \\
\text { propylcyclohexan-1-ol }\end{array}$ & 441.13 & 7.48 & 8 & 40.46 \\
\hline Analog-7 & $\begin{array}{l}\text { (1R, 2S, 4R, 6S)-2-[(1R, 2S, 5S)-2-hydroxy-5- } \\
\text { propylcyclohexyl]-6-[(1R, 2R, 5S)-2- } \\
\text { (hydroxymethyl)-5-propylcyclohexyl]-4- } \\
\text { propylcyclohexan-1-ol }\end{array}$ & 436.7107 & 6.36 & 9 & 60.69 \\
\hline
\end{tabular}

*logP: is the octanol-water partition coefficient, a measure of lipophilicity; **RB: Rotatable bond count; ***PSA: Polar surface area 
Table 5-AutoDock results of the Dunnianol analogs against FtsZ

\begin{tabular}{|c|c|c|c|c|c|}
\hline Dunnianol analog & $\begin{array}{c}\text { Binding } \\
\text { energy } \\
(\mathrm{Kcal} / \mathrm{mol})\end{array}$ & $\begin{array}{c}\mathrm{K}_{\mathrm{i}}^{*} \\
(\mathrm{nM})\end{array}$ & $\begin{array}{c}\text { Intermolecular } \\
\text { energy (Kcal/mol) }\end{array}$ & $\begin{array}{c}\text { Internal } \\
\text { energy } \\
\text { Kcal/mol) }\end{array}$ & $\begin{array}{c}\text { Docking } \\
\text { energy** } \\
(\mathrm{Kcal} / \mathrm{mol})\end{array}$ \\
\hline Analog-1 & -8.40 & 691.39 & -11.98 & -2.88 & -14.86 \\
\hline Analog-2 & -9.99 & 47.70 & -13.57 & -4.88 & -18.45 \\
\hline Analog-3 & -10.78 & 12.57 & -13.76 & -0.44 & -14.20 \\
\hline Analog-4 & -10.92 & 9.97 & -14.20 & -1.75 & -15.95 \\
\hline Analog-5 & -9.89 & 56.26 & -12.87 & -2.58 & -15.45 \\
\hline Analog-6 & -10.71 & 14.07 & -13.69 & -1.67 & -15.36 \\
\hline Analog-7 & -8.10 & 1150.00 & -11.68 & -4.46 & -16.14 \\
\hline
\end{tabular}

$* \mathrm{~K}_{\mathrm{i}}$ is the inhibition constant, **Docking energy is the sum of intermolecular and internal energies.

\section{Conclusion}

Natural products could be a potential source of new antimicrobials if their mechanism of action and their adverse effects are fully investigated. Three targets are promising, the binding site for GTP, the interaction with other components e.g. FtsA and the polymerization/depolymerization reaction of FtsZ filaments. The modification of structure may improve the efficacy or reduce the toxicity. Dunninaol and other natural products in this study could be possible inhibitors of FtsZ. This inhibition may be an alternative target in antibiotic design. 


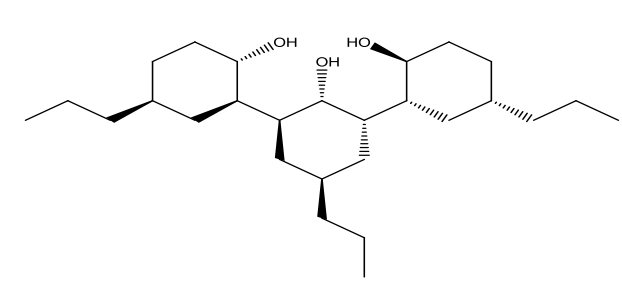

a

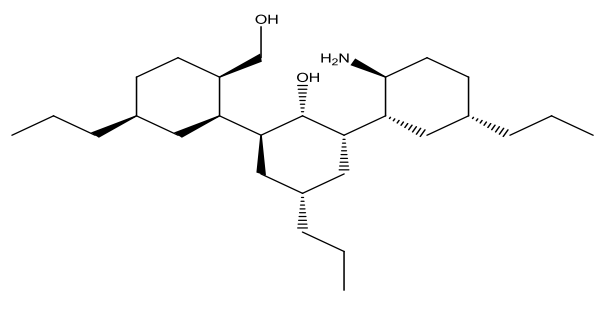

C

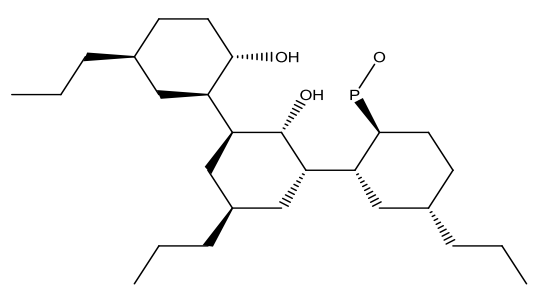

e

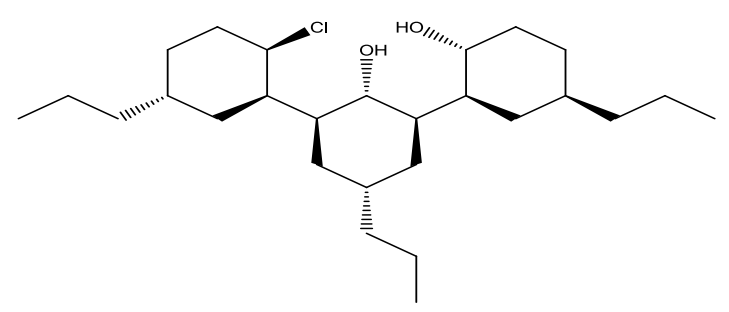

g

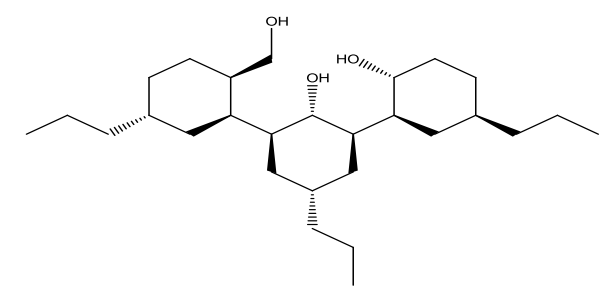

b

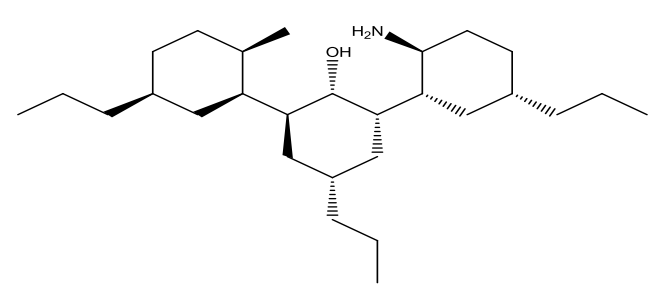

d

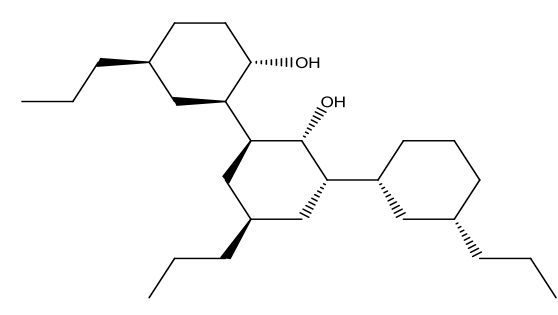

$\mathbf{f}$

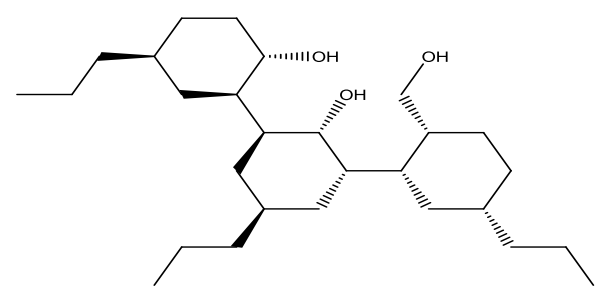

h

Fig. 8(a) Chemical structure of Dunnianol. (b-h) are Dunnianol analogs 1-7 respectively sketched by ChemBioDraw. 


\section{References}

1. de Boer P.A., Cook W.R. and Rothfield L.I., Annual. Rev. Genet., 24:249-274 (1990)

2. Erickson H.P., Cell, 80:367-370 (1995)

3. Adams D.W. and Errington J., Nat. Rev. Microbiol., 7:642-653(2009)

4. Weiss D.S., Mol. Microbiol., 54:588-597 (2004)

5. Margolin W., Nat. Rev. Mol. Cell Biol., 6:862-871 (2005)

6. Oliva M.A., Cordel S.C. and Lowe J., Nat. Struct. Mol. Biol., 11:12431250 (1998)

7. Li Z., Trimble M.J., Brun Y.V. and Jensen G.J., EMBO J., 26:46944708 (2007)

8. Erickson H.P., Anderson D.E. and Osawa M., Microbiol. Mol. Biol. Rev., 74:504-528 (2010)

9. Buske P.J. and Levin P.A., J. Biol. Chem., 287:10945-10957 (2012)

10.Löwe J. and Amos L.A., Nature, 391:203-206 (1998)

11.Haydon D.J., Stokes N.R., Ure R., Galbraith G., Bennett J.M., Brown D.R., Baker P.J., Barynin V.V., Rice D.W., Sedelnikova S.E., Heal J.R., Sheridan J. M., Aiwale S.T., Chauhan P.K., Srivastava A., Taneja A., Collins I., Errington J. and Czaplewski L.G., Science, 321:1673-1675 (2008)

12.Zhang Y., Curr. Opin. Struct. Biol., 18:342-348 (2008)

13.Marti-Renom M.A., Stuart A.C., Fiser A., Sanchez R., Melo F. and Sali A. Annu. Rev. Biophys Biomol. Struct., 29:291-325 (2000)

14.Samant L.R., Sangar V.C. and AbhayChowdhary A., Int. J. Pharm. Sci. Rev. Res., 28:123-127 (2014)

15.Lesk A.M and Chothia C., J. Mol. Biol., 136:225-270 (1980)

16.Sanchez R. and Sali A., Proc. Natl. Acad. Sci. USA, 95:13597-13602 (1998)

17.Kinch L., Yong Shi S., Cong Q., Cheng H., Liao Y. and Grishin N.V., Proteins, 79:59-73 (2011)

18.Pucci M.J., Thanassi J.A., Discotto L.F., Kessler R.E. and Dougherty T.J.J., J. Bacteriol., 179:5632-5635 (1997)

19. Gill S.C. and von Hippel P.H. Anal. Biochem., 182:319-326 (1989)

20. Guruprasad K., Reddy B.V.B. and Pandit M.W., Protein Eng., 4:155$161(1990)$

21. Ikai A.J., J. Biochem., 88:1895-1898 (1980)

22. Kyte J. and Doolittle R.F., J. Mol. Biol., 157:105-132 (1982)

23. Gasteiger E., Hoogland C., Gattiker A., Duvaud S., Wilkins M.R., Appel R.D. and Bairoch A. "The Proteomics Protocols Handbook". Humana Press, New Jersey (2005)

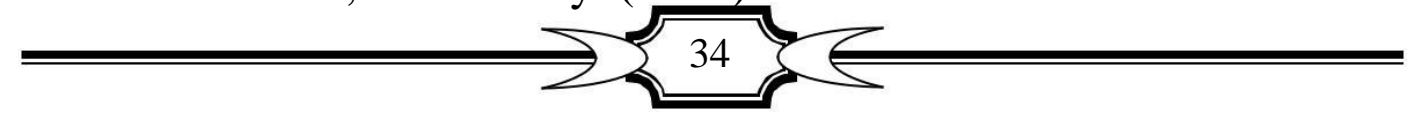


24.Cheng J., Randall A., Sweredoski M. and Baldi P., Nucleic Acids Res., 33:W72-76 (2005)

25.Kabsch W. and Sander C., Biopolymers, 22:2577-2637 (1983)

26.McGuffin L.J., Bioinformatics, 24:1789-1804 (2008)

27.Arnold K., Bordoli L., Kopp J. and Schwede T., Bioinformatics, 22:195201 (2006)

28.Guex N., Peitsch M.C. and Schwede T., Electrophoresis, 30:162-173 (2009)

29.Hall T.A., Nucl. Acids Symp. Ser., 41:95-98 (1999)

30.Kelley L.A. and Sternberg M.J. Nat. Protocols, 4:363-371 (2009)

31.Sanner M.F., J. Mol. Graphics Mod., 17:57-61 (1999)

32.Colovos C. and Yeates T.O., Protein Sci., 2:1511-1519 (1993)

33.Melo F., Devos D., Depiereux E. and Feytmans E., Int. Conf. Intell. Syst. Mol. Biol., 5:187-190 (1997)

34.Benkert P., Biasini M., and Schwede T., Bioinformatics, 27:343-350 (2011)

35.Laskowski R.A., MacArthur M.W., Moss D. and Thornton J.M., J. Appl. Cryst., 26:283-291(1993)

36.Castrignano T., De Meo P.D., Cozzetto D., Talamo I.G. and Tramontano A., Nucleic Acids Res., 34:D306-309 (2006)

37.Irwin J.J., Sterling T., Michael M.M., Bolstad E.S. and Coleman R.G., J. Chem. Inf. Model., 52:1757-1768 (2012)

38.O'Boyle N.M., Banck M., James C.A., Morley C., Vandermeersch T. and Hutchison G.R., J. Cheminformatics, 3:33 (2011)

39.Modi V., Mathur N. and Pathak A.N., Inter. J. Sci. Res. Pub., 3:1-7 (2013)

40.Ashokan K.V., Inter. J. Environ. Sci., 1:314-322 (2010)

41.Strack D., Phytochemistry, 57:144 (2001)

42.Morris G.M., Huey R., Lindstrom W., Sanner M.F., Belew R.K., Goodsell D.S. and Olson A.J., J. Comput. Chem., 30:2785-2791 (2009)

43.Garner E., Cannon P., Romero P., Obradovic Z. and Dunker A.K., Genome Informatics, 9:201-214 (1998)

44.Dyson H.J. and Wright P.E., Curr. Opin. Struct. Biol., 12:54-60 (2002)

45.Murzin A.G., Brenner S.E., Hubbard T. and Chothia C., J. Mol. Biol., 247: 536-540 (1995)

46.Shen M -Y. and Sali A. Protein Sci., 15:2507-2524 (2006)

47.Demchuk O., Karpov P., Raspor P. and Blume Y., Acta. Biologica Slovenica, 54:15-30 (2011)

48.Kapoor S. and Panda D., Exp. Opin. Ther. Targets, 13:1-15 (2009)

49.Godowski K.C., J. Clin. Dent., 1:96-101 (1989) 
In Silico Structural Analysis of The Cell Division Protein, FtsZ: ...

50.Beuria T.K., Santra M.K and Panda D., Biochemistry, 44:16584-16593 (2005)

51.Dong C., Liu L., Luo H., Li X., Guan Z. and Wang Y., Nat. Prod. Bioprospect., 2:133-137 (2012)

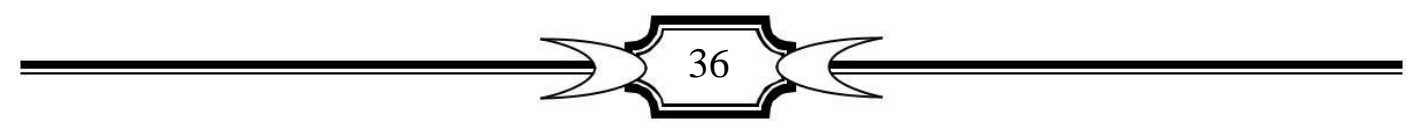

